\title{
Estimation of Evapotranspiration by Various Net Radiation Estimation Formulae for Non-Irrigated Grass in Brazil
}

\author{
Antonio Ribeiro da Cunha ${ }^{1}$, Edgar Ricardo Schöffel ${ }^{2}$, Clovis Alberto Volpe ${ }^{1}$ \\ ${ }^{1}$ School of Agronomic Sciences, São Paulo State University (UNESP), Botucatu, Brazil \\ ${ }^{2}$ Eliseu Maciel School of Agronomy, Federal University of Pelotas, Pelotas, Brazil \\ Email: arcunha@fca.unesp.br
}

Received 6 September 2014; revised 2 October 2014; accepted 27 October 2014

Copyright @ 2014 by authors and Scientific Research Publishing Inc.

This work is licensed under the Creative Commons Attribution International License (CC BY). http://creativecommons.org/licenses/by/4.0/

(c) (i) Open Access

\section{Abstract}

The objective of this study was to assess the accuracy of estimating evapotranspiration (ET) using the FA0-56 Penman-Monteith (FAO-56-PM) model, with measured and estimated net radiation $\left(\mathrm{Rn}_{\text {measured }}\right.$ and $\mathrm{Rn} \mathrm{n}_{\text {estimated, }}$ respectively), the latter obtained via five different models. We used meteorological data collected between August 2005 and June 2008, on a daily basis and on a seasonal basis (wet vs. dry seasons). The following data were collected: temperature; relative humidity; global global solar radiation (Rs); wind speed and soil heat flux. The atmospheric pressure was determined by aneroid barograph, and sunshine duration was quantified with a Campbell-Stokes recorder. In addition to the sensor readings $\left(\mathrm{Rn}_{\text {measured }}\right)$, five different models were used in order to obtain the $\mathrm{Rn}_{\text {estimated. }}$ Four of those models consider the effects of cloud cover: the original Brunt model; the FAO-24 model for wet climates; the FAO-24 model for dry climates, and the FAO-56 model. The fifth was a linear regression model based on Rs. In estimating the daily ET0 with the FA0-56-PM model, $\mathrm{Rn}_{\text {measured }}$ can be replaced by $\mathrm{Rn}_{\text {estimated, }}$ in accordance with the FAO-24 model for dry climates, with a relative error of $2.9 \%$, or with the FA0-56 model, with an error of $4.9 \%$, when $\mathrm{Rs}$ is measured, regardless of the season. The $\mathrm{Rn}_{\text {estimated }}$ obtained with the fifth model has a relatively high error. The original Brunt model and FAO-24 model for wet climates performed more poorly than did the other models in estimating the Rn and ETO. In overcast conditions, the original Brunt model, the FAO-24 model for wet climates, the FAO-24 model for dry climates, the FA0-56 model and the model of linear regression with Rs as the predictor variable tended to overestimate Rn and ET, those estimates becoming progressively more accurate as the cloud cover diminished.

\footnotetext{
"Corresponding author.
} 


\section{Keywords}

\section{Evapotranspiration, Net Radiation, Solar Radiation, Cloud Cover, Empirical Models}

\section{Introduction}

The model employed in order to quantify the consumption of water by crops includes the concept of evapotranspiration (ET), which is the rate at which water is transferred into the air from a reference surface. The model uses the FAO-56 Penman-Monteith (FAO-56-PM) equation, with a grass height of $0.12 \mathrm{~m}$, an albedo of 0.23 and a surface resistance of $70 \mathrm{~s} \cdot \mathrm{m}^{-1}$ [1], with uniform height, actively growing, covering the entire surface of the soil and without any water shortage.

The application of the FAO-56-PM model requires measurements of net radiation (Rn), soil heat flux, air temperature, humidity, atmospheric pressure and wind speed. Specifically in the case of Rn, there are procedures for estimating its value, as described by various authors [1] [2]. In many cases, because they are simple, empirical equations, the accuracy of the model in estimating Rn affects the value of ET. The uncertainty in estimating ET can be minimized by measuring Rn directly, which allows the measured and estimated values $\left(\mathrm{Rn}_{\text {measured }}\right.$ and $\mathrm{Rn}_{\text {estimated, }}$, respectively) to be compared [3].

The net radiometer is the most widely used instrument for the measurement of Rn. However, Rn is not often measured in weather station networks [4] [5].

Various studies have evaluated measured or estimated ET on several times scales, Rn having been measured by different instruments or estimated by different models [6]-[9]. The choice of methodology depends on factors such as climatic conditions, accessibility of the necessary meteorological data, complexity of the model, grouping of the data considered and costs [10] [11].

Many researchers, in the absence of experimental observations, have estimated Rn from empirical relationships based on physical considerations or other meteorological data [12], using the correlations as a function of global solar radiation (Rs). Thus, they have evaluated surfaces such as grass [13]-[16] and crops such as cotton, beans and soybeans [17], bananas [18], coffee [19], cowpeas [20], sunflowers [21], and grapes [22] [23], making the estimation of Rn simpler and more reliable because of the strong correlations found by these authors.

$\mathrm{Rn}$ is the meteorological element that has the greatest influence on ET and represents the main source of energy used in various physical-biological processes. Furthermore, it is the main parameter used in many of the models that estimate the transfer of water from vegetated surfaces into the atmosphere. It is therefore important to measure or estimate Rn accurately. In the present study, we aimed to evaluate the accuracy of estimated evapotranspiration on a daily scale during dry and wet seasons, testing various Rn estimation formulae for non-irrigated grass in Brazil.

\section{Material and Methods}

Measurements were taken at the agrometeorological station of the São Paulo State University School of Agricultural and Veterinary Sciences, located in the city of Jaboticabal, Brazil $\left(21^{\circ} 14^{\prime} 05\right.$ "S; 48 $17^{\prime} 09^{\prime \prime} \mathrm{W}$, altitude: $615.01 \mathrm{~m})$. The surface studied was covered by grass. According to the Köppen climate classification system [24], the climate of the area is type Aw, which is defined as "tropical wet and dry", or "tropical savanna" (annual climatological data: average air temperature of $22.2^{\circ} \mathrm{C}$; average relative humidity of $70.8 \%$; rainfall of 1424.6 $\mathrm{mm})$.

The experimental data were collected from August 2005 to June 2008-monthly meteorological data (Table 1) in an area of 0.56 ha $(80 \times 70 \mathrm{~m})$ covered with non-irrigated grass (Paspalum notatum L.).

The months of January, February, March, October, November and December were considered the wettest months, whereas April, May, June, July, August and September were considered the driest months [25].

ET by the FAO-56-PM model, as described by [1]:

$$
\mathrm{ET}=\frac{0.408 s(\mathrm{Rn}-G)+\gamma \frac{900}{T+273} U_{2}\left(e_{s}-e_{a}\right)}{s+\gamma\left(1+0.34 U_{2}\right)}\left(\mathrm{mm}^{-2} \cdot \mathrm{day}^{-1}\right)
$$


Table 1. Monthly meteorological data between August 2005 and June 2008.

\begin{tabular}{|c|c|c|c|c|c|c|}
\hline Month & $T\left({ }^{\circ} \mathrm{C} \cdot\right.$ day $\left.^{-1}\right)$ & RH $\left(\% \cdot\right.$ day $\left.^{-1}\right)$ & $\mathrm{P}\left(\mathrm{mm} \cdot\right.$ day $\left.^{-1}\right)$ & $U_{2}\left(\mathrm{~m} \cdot \mathrm{s}^{-1} \cdot \mathrm{day}^{-1}\right)$ & $n\left(h \cdot\right.$ day $\left.^{-1}\right)$ & $\operatorname{Rn}\left(\mathrm{MJ} \cdot \mathrm{m}^{-2} \cdot\right.$ day $\left.^{-1}\right)$ \\
\hline Jan & 23.7 & 78.4 & 412.7 & 1.7 & 5.4 & 10.1 \\
\hline Feb & 24.0 & 78.1 & 348.6 & 1.6 & 7.0 & 11.7 \\
\hline Mar & 24.0 & 73.3 & 86.8 & 1.5 & 7.5 & 10.8 \\
\hline Ap & 22.7 & 71.8 & 168.7 & 1.5 & 7.9 & 11.5 \\
\hline May & 19.2 & 66.9 & 166.9 & 1.9 & 7.1 & 9.2 \\
\hline Jun & 19.5 & 63.2 & 8.7 & 1.0 & 7.4 & 9.2 \\
\hline Jul & 19.3 & 55.9 & 80.5 & 1.9 & 7.7 & 9.9 \\
\hline Aug & 22.0 & 54.3 & 0.0 & 1.1 & 9.3 & 12.6 \\
\hline Sep & 22.8 & 56.2 & 1.3 & 1.5 & 8.0 & 13.3 \\
\hline Oct & 24.8 & 63.7 & 35.0 & 2.1 & 7.6 & 10.3 \\
\hline Nov & 23.7 & 66.8 & 129.4 & 2.4 & 7.4 & 11.5 \\
\hline Dec & 23.8 & 73.2 & 194.8 & 2.3 & 6.7 & 11.4 \\
\hline Full Period & 22.5 & 66.9 & 1633.4 & 1.7 & 7.4 & 10.9 \\
\hline
\end{tabular}

$T$, air temperature; RH, air relative humidity; P, rainfall; $U_{2}$, wind speed $-2 \mathrm{~m} ; n$, sunshine duration; Rn, net radiation.

where $G$ is the soil heat flux $\left(\mathrm{MJ} \cdot \mathrm{m}^{-2} \cdot \mathrm{day}^{-1}\right), \gamma$ is the psychrometric coefficient $\left(\mathrm{kPa}{ }^{\circ} \mathrm{C}^{-1}\right) ; T$ is the mean temperature $\left({ }^{\circ} \mathrm{C}\right) ; U_{2}$ is the mean wind speed at a height of $2 \mathrm{~m}\left(\mathrm{~m}^{-1} \mathrm{~s}^{-1}\right), e_{s}$ is the saturated vapor pressure $(\mathrm{kPa})$, given by the expression:

$$
e_{s}=0.6108 \exp ^{\left(\frac{17.27 T}{T+237.3}\right)}
$$

$e_{a}$ is the actual vapor pressure $(\mathrm{kPa})$, given by the expression:

$$
e_{a}=e_{s} \mathrm{RH}
$$

where $\mathrm{RH}$ is relative humidity (\%) and $s$ is the slope of the curve of vapor pressure $\left(\mathrm{kPa} \cdot{ }^{\circ} \mathrm{C}^{-1}\right)$, given by the expression:

$$
s=\frac{4098 e_{s}}{(T+237.3)^{2}}
$$

An automated data logger (CR10X; Campbell Scientific, Logan, UT) was installed on the reference surface in order to collect the following data (from the following instruments): temperature and relative humidity at $1.5 \mathrm{~m}$ above the surface (CS500 probe; Vaisala, Helsinki, Finland); Rs (CM3 pyranometer; Kipp \& Zonen, Delft, The Netherlands); wind speed at $2 \mathrm{~m}$ above the surface (014A-L-34 wind speed sensor; Met-One Instruments, Grants Pass, OR), and Rn (NR-Lite net radiometer; Kipp \& Zonen). Measurements of Rn were corrected for the effects of wind according to the manufacturer's recommendation. The soil heat flux was obtained with a heat flux plate (HFT3; REBS Inc., Seattle, WA) installed at a depth of $3.5 \mathrm{~cm}$. The atmospheric pressure was obtained by aneroid barograph (290; Lambrecht Meteorological Instruments, Göttingen, Germany), and sunshine duration was quantified with a Campbell-Stokes recorder (L-1603; Lambrecht Meteorological Instruments).

In addition to the $\mathrm{Rn}_{\text {measured }}, \mathrm{Rn}_{\text {estimated }}$ was obtained by combining the Angström-Prescott equations for shortwave radiation components with the Brunt equation for the longwave radiation component emitted by the atmosphere. Thus, the $\mathrm{Rn}_{\text {estimated }}$ values were obtained using four models that take into account the effects of cloud cover and a fifth model involving linear regression with Rs as the predictor variable:

$\mathbf{R n}_{\text {BRUNT }}$ : original equation of Brunt [26]:

$$
\operatorname{Rn}_{\text {BRUNT }}=[\operatorname{Rs}(1-r)]-\left[4.8989 \times 10^{-9} T^{4}(0.56-0.09 \sqrt{e a})\left(0.1+0.9 \frac{n}{N}\right)\right]\left(\mathrm{MJ} \cdot \mathrm{m}^{-2} \cdot \mathrm{day}^{-1}\right)
$$


where Rs is the global solar radiation $\left(\mathrm{MJ} \cdot \mathrm{m}^{-2} \cdot \mathrm{day}^{-1}\right), r$ is the reflection coefficient of grass, $T$ is the mean temperature (K), ea is the actual vapor pressure in the air (mmHg), $n$ is the number of hours of sunshine duration (h), and $N$ is the photoperiod (h).

$\mathbf{R n}_{\text {FAO-24W }}$ and $\mathbf{R} \mathbf{n}_{\text {FAO-24D }}$ : the Brunt equation, as adapted, in two forms [2]:

$$
\begin{aligned}
\mathrm{Rn}_{\mathrm{FAO}-24 \mathrm{~W}} & =[\operatorname{Rs}(1-r)]-\left[4.903 \times 10^{-9} T^{4}(0.56-0.25 \sqrt{e a})\left(0.1+0.9 \frac{n}{N}\right)\right](\text { wet climates }) \\
\operatorname{Rn}_{\mathrm{FAO}-24 \mathrm{D}} & =[\operatorname{Rs}(1-r)]-\left[4.903 \times 10^{-9} T^{4}(0.34-0.14 \sqrt{e a})\left(0.1+0.9 \frac{n}{N}\right)\right](\text { dry climates })
\end{aligned}
$$

$\mathbf{R n}_{\text {FAO-56: }}$ FAO-56 equation [1]:

$$
\mathrm{Rn}_{\mathrm{FAO}-56}=[\operatorname{Rs}(1-r)]-\left[4.903 \times 10^{-9} T^{4}(0.34-0.14 \sqrt{e a})\left(1.35 \frac{\mathrm{Rs}}{\mathrm{Rso}}-0.35\right)\right]
$$

where

$$
\begin{gathered}
\text { Rso }=\left[0.75+2 \times 10^{-5} z\right] \mathrm{Ra} \\
\mathrm{Ra}=\frac{1440}{\pi} G_{s c} d_{r}\left[w_{s} \sin (\varphi) \sin (\delta)+\cos (\varphi) \cos (\delta) \sin \left(w_{s}\right)\right] \\
d_{r}=1+0.033 \cos \left(\frac{2 \pi}{365} J\right) \\
\delta=0.409 \sin \left(\frac{2 \pi}{365} J-1.39\right) \\
w_{s}=\arccos [-\tan (\varphi) \tan (\delta)]
\end{gathered}
$$

where Rso is the global solar radiation without the presence of clouds $\left(\mathrm{MJ} \cdot \mathrm{m}^{-2} \cdot \mathrm{day}^{-1}\right), \mathrm{z}$ is the altitude $(\mathrm{m}), R a$ is the extraterrestrial radiation $\left(\mathrm{MJ} \cdot \mathrm{m}^{-2} \cdot \mathrm{day}^{-1}\right), G_{s c}$ is the solar constant $\left(0.0820 \mathrm{MJ} \cdot \mathrm{m}^{-2} \cdot \mathrm{min}^{-1}\right), d_{r}$ is the relative Earth-Sun distance (rad), $\delta$ is the solar declination (rad), $\varphi$ is latitude (rad), $\omega_{s}$ is the solar hour angle (rad), and $J$ is the Julian day of the year (1 to 365 or 366).

$\mathbf{R n}_{\mathbf{R s}}$ : equation for estimating the Rn at Jaboticabal linear regression with global solar radiation as the predictor variable, as proposed by André and Volpe [27]:

$$
\begin{aligned}
\mathrm{Rn}_{\mathrm{Rs}} & =0.67+0.78(\mathrm{Rs}) \text { (spring-summer) } \\
\mathrm{Rn}_{\mathrm{Rs}} & =-3.85+0.94(\mathrm{Rs}) \text { (fall-winter) }
\end{aligned}
$$

where Rs is the global solar radiation $\left(\mathrm{MJ} \cdot \mathrm{m}^{-2} \cdot \mathrm{day}^{-1}\right)$.

We adopted the cloud cover classification system proposed [28] using the clearness index $\left(K_{T}\right)$ which is the ratio between incident global solar radiation and extraterrestrial radiation: $K_{T}<0.35$ (overcast), $0.35 \leq K_{T}<0.55$ (broken clouds), $0.55 \leq K_{T} \leq 0.65$ (scattered clouds) and $K_{T}>0.65$ (clear sky).

We compared the estimation of ET based on $\mathrm{Rn}_{\text {measured }}$ with that based on $\mathrm{Rn}_{\text {estimated }}$ using the five models mentioned previously, through the statistical indicators simple linear regression analysis through the origin $(y=$ $b x)$, index of agreement (d), mean relative error (MRE) and efficiency (EF) [29]:

$$
\begin{gathered}
d=1-\left[\frac{\sum_{i=1}^{n}\left(P_{i}-O_{i}\right)^{2}}{\sum_{i=1}^{n}\left(\left|P_{i}-\bar{O}\right|+\left|O_{i}-\bar{O}\right|\right)^{2}}\right] \\
\operatorname{MRE}=\frac{1}{n} \sum_{i=1}^{n}\left(O_{i}-P_{i}\right)
\end{gathered}
$$




$$
\mathrm{EF}=\frac{\sum_{i=1}^{n}\left(O_{i}-\bar{O}\right)^{2}-\sum_{i=1}^{n}\left(O_{i}-P_{i}\right)^{2}}{\sum_{i=1}^{n}\left(O_{i}-\bar{O}\right)^{2}}
$$

where $d$ is the index of agreement, $P i$ is the ET estimated by the FAO-56-PM model with $\mathrm{Rn}_{\text {estimated }}$ via the model in question $\left(\mathrm{Rn}_{\mathrm{BRUNT}} ; \mathrm{Rn}_{\mathrm{FAO}-24 \mathrm{~W}}\right.$; $\mathrm{Rn}_{\mathrm{FAO}-24 \mathrm{D}} ; \mathrm{Rn}_{\mathrm{FAO}-56} ;$ or $\left.\mathrm{Rn}_{\mathrm{RS}}\right), O_{i}$ is the ET estimated by the FAO-56-PM model with $\mathrm{Rn}_{\text {measured }}$ (the standard), $\bar{P}$ is the mean ET obtained by the FAO-56-PM model with $\mathrm{Rn}_{\text {estimated }}$ via the alternative model in question, $\bar{O}$ is the mean ET obtained by the FAO-56-PM model with $\mathrm{Rn}_{\text {measured }}$, and $n$ is the number of observations.

\section{Results and Discussion}

Analyzing the mean monthly ET values shown in Figure 1, which were obtained from the daily mean values, and comparing the $\mathrm{Rn}_{\text {measured }}$ ET with the $\mathrm{Rn}_{\text {estimated }}$ ET from the various models, we can see that the models in which the $\mathrm{Rn}_{\text {estimated }}$ most closely approximated the $\mathrm{Rn}_{\text {measured }}$ were the $\mathrm{Rn}_{\mathrm{FAO}-24 \mathrm{D}}$ and $\mathrm{Rn}_{\mathrm{FAO}-56}$ models. In addition, the $\mathrm{Rn}_{\mathrm{Rs}}$ equation was shown to have overestimated $\mathrm{Rn}$, whereas there was an underestimation of $\mathrm{Rn}$ when the Brunt and FAO-24D equations were applied.

Initially, we analyzed the dry and wet months separately to determine the effect of seasonality of rainfall (Table 2).

Despite the similarity of the equations applied in the $\mathrm{Rn}_{\mathrm{FAO}-24 \mathrm{D}}$ and $\mathrm{Rn}_{\mathrm{FAO}-56}$ models, which differ only in the effect of cloud cover, there were significant differences between those two models. When we analyzed the dry months separately from the wet months, the $\mathrm{Rn}_{\mathrm{FAO}-56}$ model underestimated the cloud cover, by $8.5 \%$ in the dry months and $22.9 \%$ in the wet months, resulting in the estimated ET being $1.6 \%$ and $2.8 \%$ higher in the dry and wet months, respectively, relative to the estimates obtained with the $\mathrm{Rn}_{\mathrm{FAO}-24 \mathrm{D}}$ model. When we analyzed the dry and wet months together, the $\mathrm{Rn}_{\mathrm{FAO}-56}$ model underestimated the cloud cover by $15.2 \%$, increasing the estimated ET by $4.9 \%$ (Table 3). However, no statistically significant differences were observed between the separate and

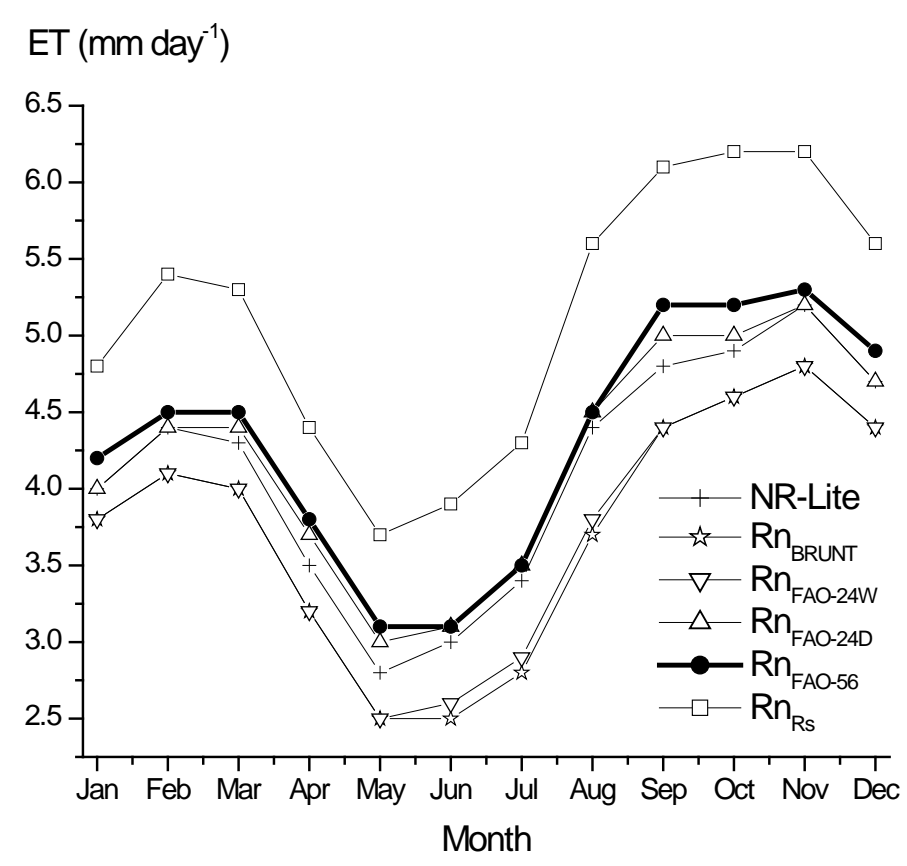

Figure 1. Monthly variation in the evapotranspiration (ET) estimates obtained with the FAO-56 Penman-Monteith model, including net radiation (Rn) measured with a net radiometer (NR-Lite) and Rn estimated via five different models: $\mathrm{Rn}_{\mathrm{BRUNT}}$; $\mathrm{Rn}_{\mathrm{FAO}-24 \mathrm{~W}}$ (for wet climates); $\mathrm{Rn}_{\mathrm{FAO}-24 \mathrm{D}}$ (for dry climates); $\mathrm{Rn}_{\mathrm{FAO}-56}$; and linear regression with global solar radiation as the predictor variable $\left(\mathrm{Rn}_{\mathrm{Rs}}\right)$. 
Table 2. Comparative statistics for evapotranspiration (ET) estimates obtained with the FAO-56 Penman-Monteith model, for dry months and wet months, including net radiation ( $\mathrm{Rn})$ measured with a net radiometer $\left(\mathrm{Rn}_{\text {measured }}\right)$ and $\mathrm{Rn}$ estimated $\left(\mathrm{Rn}_{\text {estimated }}\right)$ via the five different models evaluated: $\mathrm{Rn}_{\text {BRUNT }}$; $\mathrm{Rn}_{\text {FAO-24W }}$ (for wet climates); $\mathrm{Rn}_{\mathrm{FAO}-24 \mathrm{D}}$ (for dry climates); $\mathrm{Rn}_{\mathrm{FAO}-56}$; and linear regression with global solar radiation as the predictor variable $\left(\mathrm{Rn}_{\mathrm{Rs}}\right)$.

\begin{tabular}{|c|c|c|c|c|c|c|c|}
\hline Rn estimation formulae & $N$ & $\begin{array}{c}\text { ET with } \mathrm{Rn}_{\text {estimated }} \\
\left(\mathrm{mm} \cdot \mathrm{day}^{-1}\right)\end{array}$ & $b$ & $R^{2}$ & $d$ & $\frac{\text { MRE }}{\left(\mathrm{mm}^{\left.- \text {day }^{-1}\right)}\right.}$ & $\mathrm{EF}$ \\
\hline ET $\left(\mathrm{Rn}_{\text {measured }}\right)$, dry month & 1063 & $3.64 \mathrm{c}$ & - & - & - & - & - \\
\hline ET ( $\left.R n_{\text {measured }}\right)$, wet month & & $4.56 \mathrm{C}$ & & & & & \\
\hline ET $\left(\mathrm{Rn}_{\text {BRUNT }}\right)$, dry month & 1063 & 3.19d & 0.8787 & 0.9536 & 0.9942 & 0.45 & 0.9807 \\
\hline ET $\left(\mathrm{Rn}_{\text {BRUNT }}\right)$, wet month & & $4.26 \mathrm{D}$ & 0.9267 & 0.9391 & 0.9978 & 0.30 & 0.9917 \\
\hline ET $\left(\mathrm{Rn}_{\mathrm{FAO}-24 \mathrm{~W}}\right)$, dry month & 1063 & $3.21 \mathrm{~d}$ & 0.8852 & 0.9534 & 0.9947 & 0.43 & 0.9823 \\
\hline ET $\left(\mathrm{Rn}_{\mathrm{FAO}-24 \mathrm{~W}}\right)$, wet month & & 4.30D & 0.9339 & 0.9407 & 0.9981 & 0.26 & 0.9923 \\
\hline ET $\left(\mathrm{Rn}_{\mathrm{FAO}-24 \mathrm{D}}\right)$, dry month & 1063 & $3.79 \mathrm{c}$ & 1.0355 & 0.9827 & 0.9990 & 0.15 & 0.9955 \\
\hline ET $\left(\mathrm{Rn}_{\mathrm{FAO}-24 \mathrm{D}}\right)$, wet month & & $4.64 \mathrm{C}$ & 1.0095 & 0.9628 & 0.9990 & 0.08 & 0.9950 \\
\hline ET $\left(\mathrm{Rn}_{\mathrm{FAO}-56}\right)$, dry month & 1063 & $3.85 b$ & 1.0531 & 0.9746 & 0.9983 & 0.21 & 0.9918 \\
\hline ET $\left(\mathrm{Rn}_{\mathrm{FAO}-56}\right)$, wet month & & 4.77B & 1.0374 & 0.9703 & 0.9985 & 0.20 & 0.9927 \\
\hline ET $\left(\mathrm{Rn}_{\mathrm{Rs}}\right)$, dry month & 1063 & $4.69 \mathrm{a}$ & 1.2804 & 0.9630 & 0.9829 & 1.05 & 0.9075 \\
\hline ET $\left(\mathrm{Rn}_{\mathrm{Rs}}\right)$, wet month & & $5.59 \mathrm{~A}$ & 1.2196 & 0.9668 & 0.9886 & 1.03 & 0.9413 \\
\hline
\end{tabular}

$N$, number of observations; $b$, slope of the regression line; $R^{2}$, coefficient of determination; $d$, index of agreement; MRE, mean relative error; EF, efficiency. Means followed by the same letter in the same column do not differ at the $5 \%$ level by t-test.

Table 3. Comparative statistics for evapotranspiration (ET) estimates obtained with the FAO-56 Penman-Monteith model, for the study period as a whole (August 2005 to June 2008), including net radiation (Rn) measured with a net radiometer $\left(R n_{\text {measured }}\right)$ and $R n$ estimated $\left(R n_{\text {estimated }}\right)$ via the five different models evaluated: $R n_{\text {BRUNT }} ; \mathrm{Rn}_{\mathrm{FAO}-24 \mathrm{~W}}$ (for wet climates); $\mathrm{Rn}_{\mathrm{FAO}-24 \mathrm{D}}$ (for dry climates); $\mathrm{Rn}$ FAO-56; and linear regression with global solar radiation as the predictor variable $\left(\mathrm{Rn}_{\mathrm{Rs}}\right)$.

\begin{tabular}{|c|c|c|c|c|c|c|c|c|c|c|c|c|c|}
\hline $\begin{array}{l}\text { Rn estimation } \\
\text { formulae }\end{array}$ & $N$ & $\begin{array}{l}\mathrm{ET} \\
(\mathrm{mm})\end{array}$ & $b$ & $R^{2}$ & $d$ & $\begin{array}{l}\text { MRE } \\
(\mathrm{mm})\end{array}$ & $\mathrm{EF}$ & $\begin{array}{c}\mathrm{Rn} \\
\left(\mathrm{MJ} \cdot \mathrm{m}^{-2}\right)\end{array}$ & $b$ & $R^{2}$ & $d$ & $\begin{array}{c}\text { MRE } \\
\left(\mathrm{MJ} \cdot \mathrm{m}^{-2}\right)\end{array}$ & $\mathrm{EF}$ \\
\hline $\mathrm{ET}\left(\mathrm{Rn}_{\text {medido }}\right)$ & 1063 & $4.1 \mathrm{c}$ & - & - & - & - & - & 9.3e & - & - & - & - & - \\
\hline $\mathrm{ET}\left(\mathrm{Rn}_{\mathrm{BRUNT}}\right)$ & 1063 & $3.7 \mathrm{~d}$ & 0.908 & 0.835 & 0.996 & 0.4 & 0.986 & $7.7 \mathrm{~d}$ & 0.814 & 0.707 & 0.968 & 1.6 & 0.892 \\
\hline $\mathrm{ET}\left(\mathrm{Rn}_{\mathrm{FAO}-24 \mathrm{~W}}\right)$ & 1063 & $3.8 \mathrm{~d}$ & 0.915 & 0.937 & 0.996 & 0.3 & 0.987 & $7.9 \mathrm{~d}$ & 0.836 & 0.716 & 0.970 & 1.4 & 0.895 \\
\hline $\mathrm{ET}\left(\mathrm{Rn}_{\mathrm{FAO}-24 \mathrm{D}}\right)$ & 1063 & 4.2bc & 1.020 & 0.975 & 0.999 & 0.1 & 0.995 & $9.8 \mathrm{c}$ & 1.013 & 0.842 & 0.986 & 0.5 & 0.905 \\
\hline $\mathrm{ET}\left(\mathrm{Rn}_{\mathrm{FAO}-56}\right)$ & 1063 & $4.3 \mathrm{~b}$ & 1.044 & 0.975 & 0.998 & 0.2 & 0.992 & $10.2 b$ & 1.057 & 0.895 & 0.984 & 0.9 & 0.813 \\
\hline $\mathrm{ET}\left(\mathrm{Rn}_{\mathrm{Rs}}\right)$ & 1063 & $5.1 \mathrm{a}$ & 1.244 & 0.965 & 0.986 & 1.0 & 0.924 & $13.8 \mathrm{a}$ & 1.425 & 0.801 & 0.949 & 4.4 & 0.589 \\
\hline
\end{tabular}

$N$, number of observations; $b$, slope of the regression line; $R^{2}$, coefficient of determination; $d$, index of agreement; MRE, mean relative error; EF, efficiency. Means followed by the same letter in the same column do not differ at the $5 \%$ level by t-test.

joint analyses of dry and wet months, for any of the models. This, together with the values for slope, coefficient of determination, index of agreement, MRE and efficiency (Table 1), made it apparent that the separate analyses were not necessary, and we were able to group the data for the entire period (Table 3), thus simplifying the analysis.

When comparing the mean $\mathrm{Rn}_{\text {measured }}$ ET for the entire period (4.1 mm·day ${ }^{-1}$, Table 3) with the mean $\mathrm{Rn}_{\text {estimated }}$ ET for the entire period obtained via the $\mathrm{Rn}_{\mathrm{BRUNT}}$ and $\mathrm{Rn}_{\mathrm{FAO}-24 \mathrm{~W}}$ models, we found that those two models unde- 
ET with $\mathrm{Rn}_{\text {estimated }}$ via $\mathrm{Rn} \mathrm{Brunt}\left(\mathrm{mm}\right.$ day $\left.^{-1}\right)$

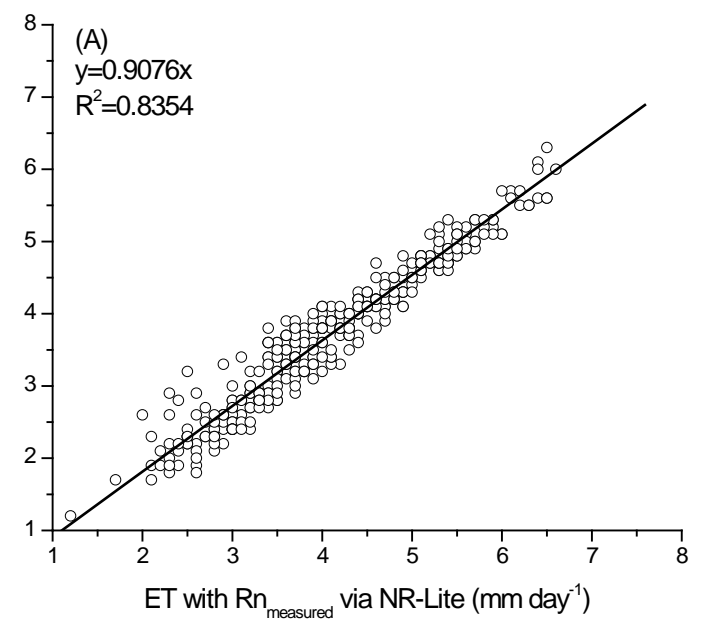

ET with $\mathrm{Rn}_{\text {estimated }}$ via $\mathrm{Rn}_{\mathrm{FAO}-24 \mathrm{D}}\left(\mathrm{mm} \mathrm{day}^{-1}\right)$

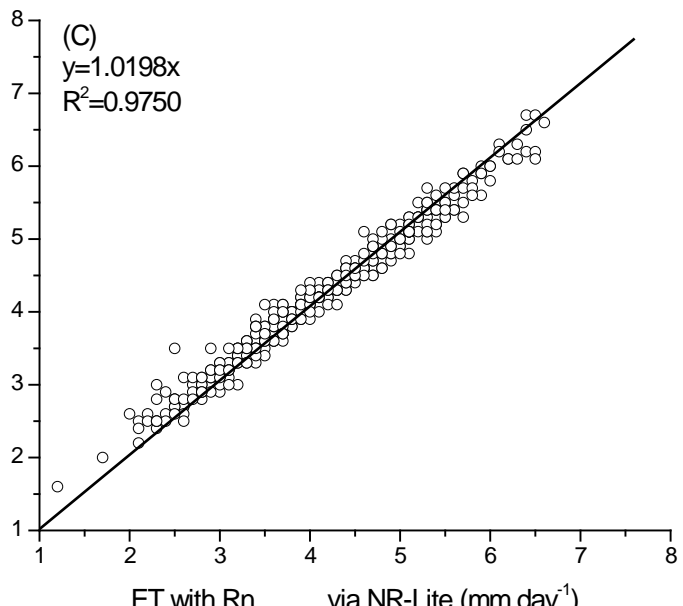

ET with $\mathrm{Rn}_{\text {estimated }}$ via $\mathrm{Rn}_{\mathrm{FAO}-24 \mathrm{~W}}\left(\mathrm{~mm} \mathrm{day}^{-1}\right)$

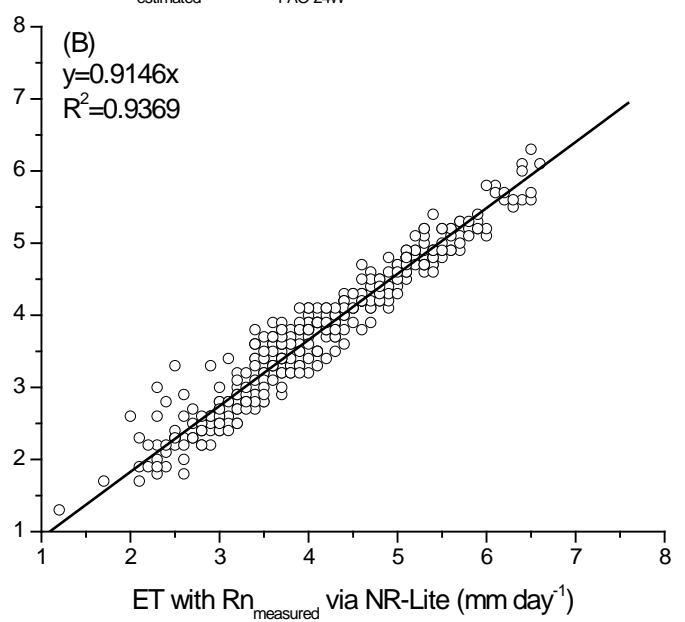

ET with $\mathrm{Rn}_{\text {estimated }}$ via $\mathrm{Rn}_{\text {FAO-56 }}\left(\mathrm{mm} \mathrm{day}^{-1}\right)$

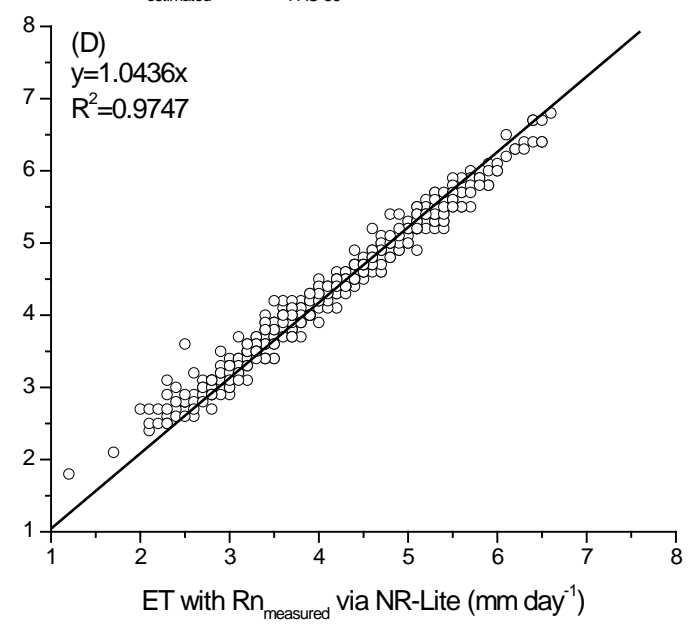

ET with $R n_{\text {estimated }}$ via $R n_{R S}\left(m m\right.$ day $\left.^{-1}\right)$

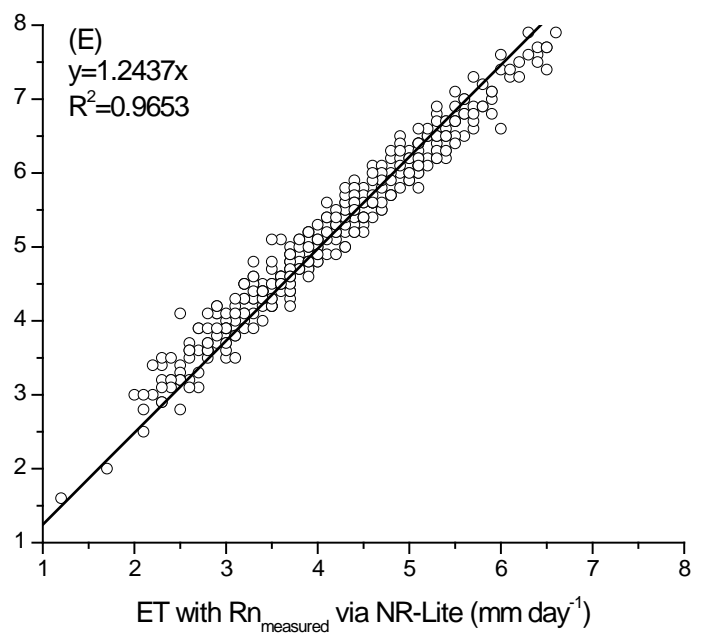

Figure 2. Relationship between the evapotranspiration (ET) estimates obtained with the FAO-56 Penman-Monteith model when net radiation $(\mathrm{Rn})$ is measured $\left(\mathrm{Rn}_{\text {measured }}\right)$ with a net radiometer (NR-Lite) and when it is estimated $\left(R n_{\text {estimated }}\right.$ ) via the five different models evaluated: (A) $\mathrm{Rn}_{\mathrm{BRUNT}}$; (B) $\mathrm{Rn}_{\mathrm{FAO}-24 \mathrm{~W}}$ (for wet climates); (C) $\mathrm{Rn}_{\mathrm{FAO}-24 \mathrm{D}}$ (for dry climates); (D) $\mathrm{Rn}_{\mathrm{FAO}-56}$; and (E) Linear regression with $\mathrm{Rs}$ as the predictor variable $\left(\mathrm{Rn}_{\mathrm{Rs}}\right)$. 
restimated the ET by $10.8 \%$ and $7.9 \%$, respectively, whereas ET was overestimated by $2.4 \%, 4.9 \%$ and $24.4 \%$, respectively, when we used the models $\mathrm{Rn}_{\mathrm{FAO}-24 \mathrm{D}}, \mathrm{Rn}_{\mathrm{FAO}-56}$ and $\mathrm{Rn}_{\mathrm{Rs}}$. A slope of the regression equation that is closer to 1 indicates a better estimate of the ET. The best fit (slope $=1.020$ ) was obtained with the $\mathrm{Rn}_{\mathrm{FAO}-24 \mathrm{D}}$ model, as confirmed by t-test (Table 3) and scatterplot (Figure 2). According to the coefficient of determination, index of agreement, mean absolute error (MAE) and efficiency values, the best estimates of ET were obtained via the $\mathrm{Rn}_{\mathrm{FAO}-24 \mathrm{D}}$ model, followed by the models $\mathrm{Rn}_{\mathrm{FAO}-56}$ models, $\mathrm{Rn}_{\mathrm{FAO}-24 \mathrm{~W}}, \mathrm{Rn}_{\mathrm{BRUNT}}$ and $\mathrm{Rn}_{\mathrm{Rs}}$. In the present study, the strongest correlation with the $\mathrm{Rn}_{\text {measured }}$ was achieved via the $\mathrm{Rn}_{\mathrm{FAO}-24 \mathrm{D}}$ model. For the study period as a whole, the MRE of Rn $\left(\mathrm{MJ} \cdot \mathrm{m}^{-2} \cdot \mathrm{day}^{-1}\right)$ was 1.6, 1.5, 0.5, 0.9 and 4.4, respectively, for the models $\mathrm{Rn}_{\mathrm{BRUNT}}$, $\mathrm{Rn}_{\text {FAO-24W, }}, \mathrm{Rn}_{\mathrm{FAO}-24 \mathrm{D}}, \mathrm{Rn}_{\mathrm{FAO}-56}$ and $\mathrm{Rn}_{\mathrm{RS}}$ (Table 3).

Some authors, such as [6] and [8], recommend using the FAO-56 equation [1] to calculate Rn when obtaining estimates of ET via the FAO-56-PM model, given that some other authors, such as [30] and [31], encountered difficulties with respect to the estimation of net longwave radiation in studies employing the FAO-24 equation. This is because the estimation of Rn requires the evaluation of several meteorological variables, including sunshine duration, which is not always possible due to the absence of measurements [32], which could make it more costly to estimate Rn than to measure it directly.

Given that estimates of ET obtained via the FAO-56-PM model are affected by the method employed in obtaining Rn, [15] recommend that Rn be obtained with the NR-Lite (Kipp \& Zonen) sensor, whereas [33] stated that Rn can be obtained with either the NR-Lite (Kipp \& Zonen) sensor or the Q-7.1 (REBS) sensor, provided that the sensor employed is properly calibrated against a CNR1 (Kipp \& Zonen) sensor, which is considered the standard for its high accuracy [34].

For the Jaboticabal region, the $\mathrm{Rn}_{\mathrm{Rs}}$ model André and Volpe [27] overestimated ET by $28.8 \%$ and $22.6 \%$ for dry and wet months, respectively, and by $24.4 \%$ for the study period as a whole (Table 2 and Table 3). This is explained in part by the fact that the regression equation was devised in 1988, with Rn measured by a net exchange radiometer (Packard Bell model TCN-188), without dome and with ventilation, and Rs measured with an Eppley thermopile pyranometer (model 8-48), instruments quite different from those currently used. Most current net radiometers consist of thermopile covered by a dome of polyethylene to eliminate natural ventilation and reduce thermal convection from the body of the device. In view of the disadvantages regarding maintenance and operation of a net radiometer with a dome, the "dome-less" NR-Lite [34], in which the dome has been replaced by a black Teflon coating [35], is now widely used.

In the present study, despite the high correlation between Rn and Rs, Rs overestimated Rn by $48.4 \%$ according to the methodology of André and Volpe [27] and, consequently, the FAO-56-PM model with Rn estimated by the $\mathrm{Rn}_{\mathrm{Rs}}$ model overestimated the daily ET by $24.4 \%$ (Table 3). Many authors have identified such overestimation of ET, ranging from $6 \%$ to $29 \%$, at various locations [15] [36]-[44].

Significant errors can be made in estimating the ET when Rn is not correctly measured or estimated, with differences of as much as $2.2 \mathrm{MJ} \cdot \mathrm{m}^{-2} \cdot \mathrm{day}^{-1}$ [45]. In the present study, when we analyzed the different cloud cover conditions, we found that the MRE for $\mathrm{Rn}_{\text {estimated }}$ was $0.2-5.1 \mathrm{MJ} \cdot \mathrm{m}^{-2} \cdot \mathrm{day}^{-1}$ for clear sky days, $0.01-3.5$ $\mathrm{MJ} \cdot \mathrm{m}^{-2} \cdot \mathrm{day}^{-1}$ for days with scattered clouds, $0.4-3.1 \mathrm{MJ} \cdot \mathrm{m}^{-2} \cdot$ day $^{-1}$ for days with broken clouds and $1.3-2.7$ $\mathrm{MJ} \cdot \mathrm{m}^{-2} \cdot \mathrm{day}^{-1}$ for overcast days (Table 4 ).

The model used in obtaining $\mathrm{Rn}$ and, specifically, the way in which the effect that cloud cover has on the longwave component is calculated, can cause significant errors in the estimation of daily ET by the PenmanMonteith model [15] [46].

The Rn depends heavily on the Rs, which is in turn dependent on other factors, such as the effect of cloud cover, increases in cloud cover decreasing the Rs and Rn fluxes and consequently decreasing the ET. This is because the clear sky condition reveals the dependence of Rn on cloud cover [47].

When ET is estimated by the Penman-Monteith model on the basis of $\mathrm{Rn}$ estimated by the $\mathrm{Rn}_{\mathrm{Rs}}$ model, the effect of cloud cover is embedded in the term Rs, but varies slightly in comparison with that of the Rn estimation models in which the effect of cloud cover is taken into account. This is because cloud cover has a major influence on variations in net longwave radiation and consequently on estimates of $\mathrm{ET}$. The $\mathrm{Rn}_{\mathrm{Rs}}$ model limits variations that other models allow, because it sets fixed values for the seasons. [12] recommend that parameters such as Rs, surface albedo, $\mathrm{K}_{\mathrm{T}}$ and air temperature, normally used to estimate $\mathrm{Rn}$, be incorporated into new elements, such as Rs and pressure of water vapor, to improve the credibility of the estimates. As cloud cover de creases, the net longwave radiation balance becomes more negative and therefore has a greater effect on the calculation of the $\mathrm{Rn}_{\text {estimated, }}$ bringing it into closer proximity with the $\mathrm{Rn}_{\text {measured }}$ (Table 5). 
Table 4. Comparative statistics for evapotranspiration (ET) estimates obtained with the FAO-56 Penman-Monteith model, under various cloud cover conditions, including net radiation $(\mathrm{Rn})$ measured with a net radiometer $\left(\mathrm{Rn}_{\text {measured }}\right)$ and $\mathrm{Rn}$ estimated $\left(R n_{\text {estimated }}\right)$ via the five different models evaluated: $\mathrm{Rn}_{\mathrm{BRUNT}}$; $\mathrm{R} \mathrm{n}_{\mathrm{FAO}-24 \mathrm{~W}}$ (for wet climates); $\mathrm{Rn}_{\mathrm{FAO}-24 \mathrm{D}}$ (for dry climates); $\mathrm{Rn}_{\mathrm{FAO}-56}$; and linear regression with global solar radiation as the predictor variable $\left(\mathrm{Rn}_{\mathrm{Rs}}\right)$.

\begin{tabular}{|c|c|c|c|c|c|c|c|c|c|c|c|c|c|}
\hline $\begin{array}{c}\text { Clearness } \mathrm{Rn} \\
\text { estimation formulae }\end{array}$ & $N$ & $\begin{array}{c}\mathrm{ET} \\
(\mathrm{mm})\end{array}$ & $b$ & $R^{2}$ & $d$ & $\begin{array}{l}\text { MRE } \\
(\mathrm{mm})\end{array}$ & $\mathrm{EF}$ & $\begin{array}{c}\mathrm{Rn} \\
\left(\mathrm{MJ} \cdot \mathrm{m}^{-2}\right)\end{array}$ & $b$ & $R^{2}$ & $d$ & $\begin{array}{c}\mathrm{MRE} \\
\left(\mathrm{MJ} \cdot \mathrm{m}^{-2}\right)\end{array}$ & $\mathrm{EF}$ \\
\hline \multicolumn{14}{|l|}{ Clear sky } \\
\hline $\mathrm{ET}\left(\mathrm{Rn}_{\text {medido }}\right)$ & 692 & $4.5 \mathrm{bc}$ & - & - & - & - & - & $10.2 \mathrm{c}$ & - & - & - & - & - \\
\hline $\mathrm{ET}\left(\mathrm{Rn}_{\mathrm{BRUNT}}\right)$ & 692 & $3.9 \mathrm{~d}$ & 0.879 & 0.926 & 0.992 & 0.6 & 0.976 & $7.8 \mathrm{~d}$ & 0.775 & 0.806 & 0.964 & 2.4 & 0.912 \\
\hline $\mathrm{ET}\left(\mathrm{Rn}_{\mathrm{FAO}-24 \mathrm{~W}}\right)$ & 692 & $4.0 \mathrm{~d}$ & 0.886 & 0.927 & 0.993 & 0.5 & 0.978 & $7.9 \mathrm{~d}$ & 0.788 & 0.808 & 0.967 & 2.3 & 0.919 \\
\hline $\mathrm{ET}\left(\mathrm{Rn}_{\mathrm{FAO}-24 \mathrm{D}}\right)$ & 692 & $4.6 \mathrm{c}$ & 1.004 & 0.933 & 0.998 & 0.1 & 0.994 & $10.4 \mathrm{c}$ & 0.998 & 0.816 & 0.994 & 0.2 & 0.974 \\
\hline $\mathrm{ET}\left(\mathrm{Rn}_{\mathrm{FAO}-56}\right)$ & 692 & $4.7 \mathrm{bc}$ & 1.025 & 0.960 & 0.999 & 0.1 & 0.993 & $10.8 \mathrm{~b}$ & 1.038 & 0.890 & 0.995 & 0.6 & 0.970 \\
\hline $\mathrm{ET}\left(\mathrm{Rn}_{\mathrm{Rs}}\right)$ & 692 & $5.7 \mathrm{a}$ & 1.250 & 0.917 & 0.983 & 1.2 & 0.903 & 15.3a & 1.443 & 0.743 & 0.948 & 5.1 & 0.593 \\
\hline \multicolumn{14}{|l|}{ Scattered clouds } \\
\hline $\mathrm{ET}\left(\mathrm{Rn}_{\text {medido }}\right)$ & 127 & $4.4 \mathrm{bc}$ & - & - & - & - & - & $10.4 \mathrm{c}$ & - & - & - & - & - \\
\hline $\mathrm{ET}\left(\mathrm{Rn}_{\mathrm{BRUNT}}\right)$ & 127 & $4.0 \mathrm{~d}$ & 0.918 & 0.856 & 0.996 & 0.3 & 0.988 & $9.0 \mathrm{~d}$ & 0.857 & 0.605 & 0.985 & 1.4 & 0.959 \\
\hline $\mathrm{ET}\left(\mathrm{Rn}_{\mathrm{FAO}-24 \mathrm{~W}}\right)$ & 127 & $4.0 \mathrm{~d}$ & 0.924 & 0.859 & 0.997 & 0.3 & 0.989 & $9.1 \mathrm{~d}$ & 0.867 & 0.612 & 0.987 & 1.3 & 0.962 \\
\hline $\mathrm{ET}\left(\mathrm{Rn}_{\mathrm{FAO}-24 \mathrm{D}}\right)$ & 127 & $4.4 \mathrm{c}$ & 0.994 & 0.896 & 0.998 & 0.01 & 0.994 & $10.4 \mathrm{c}$ & 0.988 & 0.698 & 0.995 & 0.01 & 0.979 \\
\hline $\mathrm{ET}\left(\mathrm{Rn}_{\mathrm{FAO}-56}\right)$ & 127 & $4.5 \mathrm{bc}$ & 1.030 & 0.932 & 0.990 & 0.2 & 0.993 & $11.1 \mathrm{~b}$ & 1.047 & 0.809 & 0.995 & 0.65 & 0.974 \\
\hline $\mathrm{ET}\left(\mathrm{Rn}_{\mathrm{Rs}}\right)$ & 127 & $5.2 \mathrm{a}$ & 1.184 & 0.910 & 0.991 & 0.8 & 0.954 & $13.9 \mathrm{a}$ & 1.318 & 0.786 & 0.976 & 3.5 & 0.847 \\
\hline \multicolumn{14}{|l|}{ Broken clouds } \\
\hline ET ( $\left(\mathrm{Rn}_{\text {medido }}\right)$ & 155 & $3.2 \mathrm{~d}$ & - & - & - & - & - & 7.3e & - & - & - & - & - \\
\hline ET $\left(\mathrm{Rn}_{\mathrm{BRUNT}}\right)$ & 155 & $3.3 \mathrm{~d}$ & 1.017 & 0.877 & 0.996 & 0.1 & 0.971 & 7.7e & 1.028 & 0.633 & 0.989 & 0.4 & 0.932 \\
\hline $\mathrm{ET}\left(\mathrm{Rn}_{\mathrm{FAO}-24 \mathrm{~W}}\right)$ & 155 & $3.4 \mathrm{~d}$ & 1.021 & 0.880 & 0.996 & 0.1 & 0.971 & $7.8 \mathrm{~d}$ & 1.037 & 0.643 & 0.989 & 0.5 & 0.929 \\
\hline $\mathrm{ET}\left(\mathrm{Rn}_{\mathrm{FAO}-24 \mathrm{D}}\right)$ & 155 & $3.5 \mathrm{c}$ & 1.075 & 0.912 & 0.994 & 0.3 & 0.959 & $8.5 c$ & 1.137 & 0.746 & 0.984 & 1.2 & 0.873 \\
\hline $\mathrm{ET}\left(\mathrm{Rn}_{\mathrm{FAO}-56}\right)$ & 155 & $3.6 \mathrm{bc}$ & 1.103 & 0.928 & 0.992 & 0.4 & 0.947 & $8.9 \mathrm{bc}$ & 1.184 & 0.817 & 0.979 & 1.6 & 0.799 \\
\hline $\mathrm{ET}\left(\mathrm{Rn}_{\mathrm{Rs}}\right)$ & 155 & $4.0 \mathrm{a}$ & 1.219 & 0.882 & 0.986 & 0.7 & 0.908 & $10.4 a$ & 1.410 & 0.767 & 0.962 & 3.1 & 0.726 \\
\hline \multicolumn{14}{|l|}{ Overcast } \\
\hline $\mathrm{ET}\left(\mathrm{Rn}_{\text {medido }}\right)$ & 89 & $1.8 \mathrm{c}$ & - & - & - & - & - & $3.7 \mathrm{c}$ & - & - & - & - & - \\
\hline $\mathrm{ET}\left(\mathrm{Rn}_{\mathrm{BRUNT}}\right)$ & 89 & $2.1 \mathrm{ab}$ & 1.142 & 0.927 & 0.987 & 0.3 & 0.922 & $5.1 \mathrm{~b}$ & 1.223 & 0.760 & 0.932 & 1.3 & 0.530 \\
\hline $\mathrm{ET}\left(\mathrm{Rn}_{\mathrm{FAO}-24 \mathrm{~W}}\right)$ & 89 & 2.1ab & 1.145 & 0.929 & 0.986 & 0.3 & 0.920 & $5.1 \mathrm{~b}$ & 1.231 & 0.766 & 0.930 & 1.4 & 0.516 \\
\hline $\mathrm{ET}\left(\mathrm{Rn}_{\mathrm{FAO}-24 \mathrm{D}}\right)$ & 89 & $2.2 \mathrm{ab}$ & 1.186 & 0.941 & 0.981 & 0.4 & 0.887 & $5.5 b$ & 1.325 & 0.818 & 0.909 & 1.8 & 0.278 \\
\hline $\mathrm{ET}\left(\mathrm{Rn}_{\mathrm{FAO}-56}\right)$ & 89 & $2.4 \mathrm{a}$ & 1.262 & 0.949 & 0.964 & 0.6 & 0.710 & $6.3 a$ & 1.448 & 0.866 & 0.874 & 2.5 & 0.826 \\
\hline $\mathrm{ET}\left(\mathrm{Rn}_{\mathrm{Rs}}\right)$ & 89 & $2.4 a$ & 1.294 & 0.872 & 0.959 & 0.6 & 0.800 & $6.4 a$ & 1.628 & 0.777 & 0.888 & 2.7 & 0.120 \\
\hline
\end{tabular}

$N$, number of observations; $b$, slope of the regression line; $R^{2}$, coefficient of determination; $d$, index of agreement; MRE, mean relative error; EF, efficiency. Means followed by the same letter in the same column do not differ at the $5 \%$ level by t-test.

As can be seen in Table 5, on days with overcast skies, all four of the Rn estimation models that took cloud cover into consideration overestimated the $\mathrm{Rn}$ in relation to the $\mathrm{Rn}_{\text {measured, }}$, because net shortwave radiation is directly dependent on Rs, the proportional contribution of net shortwave radiation increasing in parallel with increases in Rs. Determining the net longwave radiation depends on indices that correct for the effects of cloud 
Table 5. Partition of net radiation estimated by the four models that take the effect of cloud cover into account, under various cloud cover conditions.

\begin{tabular}{|c|c|c|c|c|c|c|c|c|}
\hline \multirow{2}{*}{ Clearness } & \multirow{2}{*}{$K_{T}$} & \multirow{2}{*}{ Rs } & \multirow{2}{*}{$\begin{array}{c}\text { Rns } \\
\text { Rn }\end{array}$} & \multicolumn{4}{|c|}{ Rnl } & \multirow{2}{*}{$\mathrm{Rn}_{\text {measured }}$} \\
\hline & & & & $\mathrm{Rn}_{\mathrm{BRUNT}}$ & $\mathrm{Rn}_{\mathrm{FAO}-24 \mathrm{~W}}$ & $\mathrm{Rn}_{\mathrm{FAO}-24 \mathrm{D}}$ & $\mathrm{Rn}_{\mathrm{FAO}-56}$ & \\
\hline Clear sky & 0.83 & 20.13 & 15.50 & -7.65 & -7.51 & -5.04 & -4.66 & 10.25 \\
\hline Scattered clouds & 0.60 & 17.50 & 13.48 & -4.48 & -4.36 & -3.03 & -2.39 & 10.44 \\
\hline Broken clouds & 0.46 & 13.41 & 10.33 & -2.62 & -2.55 & -1.78 & -1.40 & 7.28 \\
\hline Overcast & 0.26 & 7.50 & 5.77 & -1.29 & -1.26 & -0.87 & -0.02 & 3.05 \\
\hline
\end{tabular}

$K_{T}$, clearness index, Rs, global solar radiation; Rns, net shortwave radiation; Rnl, net longwave radiation, Rn, net radiation.

cover and pressure of water vapor. In the $\mathrm{Rn}_{\mathrm{BRUNT}}, \mathrm{R} \mathrm{n}_{\mathrm{FAO}-24 \mathrm{~W}}$ and $\mathrm{R} \mathrm{n}_{\mathrm{FAO}-24 \mathrm{D}}$ models, net longwave radiation has the same effect as cloud cover, changing only the indices that correct for pressure of water vapor in the air, which decreases the size of its effect, the index values being 0.47 for Equation (5), compared with 0.31 for Equation (6) and 0.20 for Equation (7).

Under conditions of clear sky, scattered clouds and broken clouds, the $\mathrm{Rn}_{\text {estimated }}$ values obtained with the $\mathrm{Rn}_{\mathrm{FAO}-24 \mathrm{D}}$ and $\mathrm{R} \mathrm{n}_{\mathrm{FAO}-56}$ models were comparable to the $\mathrm{Rn}_{\text {measured }}$. Under overcast conditions, none of the models employed was able to adequately represent the $\mathrm{Rn}_{\text {measured }}$ or the ET obtained therefrom (Table 4). The $\mathrm{Rn}$ estimated depends on the proportional contribution of net shortwave radiation and net longwave radiation. Under overcast conditions, the net longwave radiation share corresponded to only $15 \%$ - $22 \%$ of that of net shortwave radiation, which affected the estimation of $\mathrm{Rn}$, because the net shortwave radiation was more prominent. Under conditions of clear sky, the net longwave radiation share corresponded to $30 \%$ - 49\% of the net shortwave radiation share, having an even greater effect on the estimation of Rn (Table 5).

\section{Conclusions}

According to the coefficient of determination, index of agreement, MAE and efficiency values, the best estimates of ET were obtained via the $\mathrm{Rn}_{\mathrm{FAO}-24 \mathrm{D}}$ model, followed by the models $R \mathrm{n}_{\mathrm{FAO}-56}, \mathrm{Rn}_{\mathrm{FAO}-24 \mathrm{~W}}, \mathrm{R} \mathrm{n}_{\mathrm{BRUNT}}$ and $R n_{R s}$. The $R n_{\text {estimated }}$ obtained with the $R n_{F A O-24 D}$ and $R n_{F A O-56}$ models more closely approximated the $R n_{\text {measured }}$ than did that obtained with the other models. Despite the similarity of the equations applied in the $\mathrm{Rn}_{\mathrm{FAO}-24 \mathrm{D}}$ and $\mathrm{Rn}_{\mathrm{FAO}-56}$ models, which differ only in the effect of cloud cover, there were significant differences between the two models. The $\mathrm{Rn}_{\mathrm{FAO}-56}$ model underestimated the cloud cover, thereby increasing the estimated ET.

Under conditions of clear sky, scattered clouds and broken clouds, the $\mathrm{Rn}_{\text {estimated }}$ values obtained with the $\mathrm{Rn}_{\mathrm{FAO}-24 \mathrm{D}}$ and $\mathrm{R} n_{\mathrm{FAO}-56}$ models were comparable to the $\mathrm{Rn}_{\text {measured }}$ value. As cloud cover decreases, the net longwave radiation balance becomes more negative and therefore has a greater effect on the calculation of the $\mathrm{Rn}_{\mathrm{esti}}$ mated, bringing it into closer proximity with the $\mathrm{Rn}_{\text {measured }}$.

The $\mathrm{Rn}$ is the meteorological element that has the greatest influence on ET and can cause significant errors in the estimation of ET when not correctly measured or estimated.

\section{Acknowledgements}

This study received financial support from the Fundação de Amparo à Pesquisa do Estado de São Paulo (FAPESP, São Paulo Research Foundation; Grant No. 05/59535-4).

\section{References}

[1] Allen, R.G., Pereira, L.S., Raes, D. and Smith, M. (1998) Crop Evapotranspiration-Guidelines for Computing Crop Water Requirements. FAO Irrigation and Drainage Paper 56. http://www.fao.org/docrep/X0490E/X0490E00.htm

[2] Doorenbos, J. and Pruitt, W.O. (1977) Crop Water Requirements. FAO Irrigation and Drainage Paper 24, FAO, Rome, $144 \mathrm{p}$.

[3] Batchelor, C.H. (1984) The Accuracy of Evapotranspiration Estimated with the FAO Modified Penman Equation. Irrigation Science, 5, 223-233. http://dx.doi.org/10.1007/BF00258176

[4] Llasat, M.C. and Snyder, R.L. (1998) Data Error Effects on Net Radiation and Evapotranspiration Estimation. Agri- 
cultural and Forest Meteorology, 91, 209-221. http://dx.doi.org/10.1016/S0168-1923(98)00070-7

[5] Brotzge, J.A. and Crawford, K.C. (2003) Examination of the Surface Energy Budget: A Comparison of Eddy Correlation an Bowen Ratio Measurement Systems. Journal of Hydrometeorology, 4, 160-178. http://dx.doi.org/10.1175/1525-7541(2003)4<160:EOTSEB>2.0.CO;2

[6] Santiago, A.V., Pereira, A.R., Folegatti, M.V. and Maggiotto, S.R. (2002) Reference Evapotranspiration Measured with a Weighing Lysimeter and Estimated by Penman-Monteith (FAO-56) on a Monthly and Ten-Days Time Scales. Revista Brasileira de Agrometeorologia, 10, 57-66.

[7] Pereira, A.R., Sentelhas, P.C. and Folegatti, M.V. (2002) Substantiation of the Daily FAO-56 Reference Evapotranspiration with Data from Automatic and Conventional Weather Stations. Revista Brasileira de Agrometeorologia, 10, 251-257.

[8] Gavilán, P., Berengena, J. and Allen, R.G. (2007) Measuring versus Estimating Net Radiation and Soil Heat Flux: Impact on Penman-Monteith Reference ET Estimates in Semiarid Regions. Agricultural Water Management, 89, 275-286. http://dx.doi.org/10.1016/j.agwat.2007.01.014

[9] Oliveira, A.D. and Volpe, C.A. (2003) Comparison of Methods for Estimating Reference Evapotranspiration Using Data of Conventional and Automatic Weather Stations. Revista Brasileira de Agrometeorologia, 11, 253-260.

[10] Carvalho, D.F., Silva, L.D.B., Guerra, J.G.M., Cruz, F.A. and Souza, A.P. (2007) Installation, Calibration and Operation of a Weighing Lysimeter. Agricultural Engineering, 27, 363-372.

[11] Zanetti, S.S., Sousa, E.F., Carvalho, D.F. and Bernardo, S. (2008) Reference Evapotranspiration Estimate in Rio de Janeiro State Using Artificial Neural Networks. Revista Brasileira de Engenharia Agrícola e Ambiental, 12, 174-180. http://dx.doi.org/10.1590/S1415-43662008000200010

[12] Iziomon, M.G., Mayer, H. and Matzarakis, A. (2000) Empirical Models for Estimating Net Radiative Flux: A Case Study for Three Mid-Latitude Sites with Orographic Variability. Astrophysics and Space Science, 273, 313-330. http://dx.doi.org/10.1023/A:1002787922933

[13] Linacre, E. (1992) Climate Data and Resources: A Reference and Guide. Routledge, London.

[14] Snyder, R.L., Duce, P., Spano, D. and Eching, S. (1998) Hourly Estimation of Net Radiation over Grass. Proceedings of the 23rd Conference on Agriculture and Forest Meteorology, Albuquerque, 2-6 November 1998, 139-140.

[15] Turco, J.E.P., Faria, M.T. and Fernandes, E.J. (2005) Influence of Net Radiation Obtention Method Compared to the Reference Evapotranspiration Estimate Methods. Irriga, 10, 215-228.

[16] Silva, L.D.B., Folegatti, M.V., Vila Nova, N.A. and Carvalho, D.F. (2007) Relationship of Net Radiation Measurements over Bahia Grass and Guinea Grass with Incoming Global Solar Radiation in Piracicaba, São Paulo State, Brazil. Revista Brasileira de Agrometeorologia, 15, 250-256.

[17] Azevedo, P.V., Leitão, M.M.V.B.R., Sousa, I.F. and Maciel, G.F. (1990) Radiation Balance of Irrigated Crops in the Semiarid Region of Northeastern Brazil. Revista Brasileira de Meteorologia, 5, 403-410.

[18] Teixeira, A.H.C. (2001) Evaluation of Components of Energy Balance in Banana Crop during the First Year. Revista Brasileira de Engenharia Agrícola e Ambiental, 5, 28-32. http://dx.doi.org/10.1590/S1415-43662001000100006

[19] Pezzopane, J.R.M., Pedro Júnior, M.J. and Gallo, P.B. (2005) Solar and Net Radiation in a Coffee Crop Grown Unshaded and Shaded by "Prata Anã” Banana Plants. Bragantia, 64, 485-497. http://dx.doi.org/10.1590/S0006-87052005000300020

[20] Neves, L.O., Costa, J.M.N., Andrade, V.M., Lôla, A.C., Pezzopane, J.R.M. and Pedro Júnior, M.J. (2003) Energy Balance on "Niagara Rosada” Vineyard. Bragantia, 62, 155-161. http://dx.doi.org/10.1590/S0006-87052003000100019

[21] Heldwein, A.B., Maldaner, I.C., Radons, S.Z., Loose, L.H., Lucas, D.D.P. and Hinnah, F.D. (2012) Estimation of Net Radiation in Sunflower as a Function of Global Solar Radiation. Revista Brasileira de Engenharia Agrícola e Ambiental, 16, 194-199. http://dx.doi.org/10.1590/S1415-43662012000200010

[22] Azevedo, P.V., Teixeira, A.H.C., Silva, B.B., Soares, J.M. and Saraiva, F.A.M. (1997) Evaluation of the Reflectance and Net Radiation over a European Wine Grape Vineyard. Revista Brasileira de Agrometeorologia, 5, 1-7.

[23] Pezzopane, J.R.M. and Pedro Júnior, M.J. (2003) Energy Balance on “Niagara Rosada” Vineyard. Bragantia, 62, 155161. http://dx.doi.org/10.1590/S0006-87052003000100019

[24] CEPAGRI (2012) Centre for Meteorological and Climate Research Applied to Agriculture. Climate of Counties. http://www.cpa.unicamp.br/outras-informacoes/clima_muni_279.html

[25] UNESP-DCE (2012) Department of Exact Sciences-Agrometeorological Station of the Superior School of Agrarian and Veterinary Sciences. http://www.fcav.unesp.br

[26] Brunt, D. (1932) Notes in Radiation in the Atmosphere. Quarterly Journal of the Royal Meteorological Society, 58, 
389-420. http://dx.doi.org/10.1002/qi.49705824704

[27] André, R.G.B. and Volpe, C.A. (1988) Estimation of Net Radiation in Jaboticabal (SP). Revista de Geografia, 7, $1-8$.

[28] Escobedo, J.F., Gomes, E.N., Oliveira, A.P. and Soares, J. (2009) Modeling Hourly and Daily Fractions of UV, PAR and NIR to Global Solar Radiation under Various Sky Conditions at Botucatu, Brazil. Applied Energy, 86, $299-309$. http://dx.doi.org/10.1016/j.apenergy.2008.04.013

[29] Willmott, C.J., Ackleson, S.G., Davis, R.E., Feddema, J.J., Klink, K.M., Legates, D.R., O’donnell, J. and Rowe, C.M. (1985) Statistics for the Evaluation and Comparison of Models. Journal of Geophysical Research, 10, 8995-9005. http://dx.doi.org/10.1029/JC090iC05p08995

[30] Galvão, J.A.C. and Fisch, G. (2000) Radiation Balance in Pasture in the Amazon. Revista Brasileira de Agrometeorologia, 8, 1-10.

[31] Von Randow, R.C.S. and Alvalá, R.C.S. (2006) Estimation of Long-Wave Atmospheric Radiation over Pantanal Sul Mato Grossense during the Dry Seasons of 1999 and 2000. Revista Brasileira de Meteorologia, 21, 398-412.

[32] Fontana, D.C., Berlato, M.A. and Bergamaschi, H. (1991) Energy Balance in Irrigated and Non-Irrigated Soybeans. Pesquisa Agropecuária Brasileira, 26, 411-418.

[33] Cunha, A.R., Volpe, C.A. and Escobedo, J.F. (2008) Estimating Reference Evapotranspiration by Penman-Monteith Method (FAO-56) with Measured Net Radiation for Different Sensors. Agronomia Tropical, 58, 81-84.

[34] Kipp, Z. (2000) CNR1 Net Radiometer Instruction Manual. Kipp \& Zonen, Delft, 42 p.

[35] Cobos, D.R. and Baker, J.M. (2003) Evaluation and Modification of a Domeless Net Radiometer. Agronomy Journal, 95, 177-183. http://dx.doi.org/10.2134/agronj2003.0177

[36] Tagliaferre, C., Silva, R.A.J., Rocha, F.A., Santos, L.C. and Silva, C.S. (2010) Comparative Study of Different Methodologies for Determining Reference Evapotranspiration in Eunápolis-BA. Revista Caatinga, 23, 103-111.

[37] Oliveira, L.M.M., Montenegro, S.M.G.L., Azevedo, J.R.G. and Santos, F.X. (2008) Reference Evapotranspiration in the Experimental Basin of Gameleira, PE, Using Lysimeter and Indirect Methods. Revista Brasileira de Ciências Agrárias, 3, 58-67.

[38] Alencar, L.P., Delgado, R.C., Almeida, T.S. and Wanderley, H.S. (2011) Comparison of Different Methods for Daily Estimating Reference Evapotranspiration for the Region of Uberaba. Revista Brasileira de Ciências Agrárias, 6, 337343.

[39] Reis, E.F., Bragança, R., Garcia, G.O., Pezzopane, J.E.M. and Tagliaferre, C. (2007) Comparative Study of the Estimate of the Evaporate Transpiration Regarding the Three Locality State of Espirito Santo during the Dry Period. Idesia, 25, 75-84.

[40] Pereira, D.R., Yanagi, S.N.M., Mello, C.R., Silva, A.M. and Silva, L.A. (2009) Performance of the Reference Evapotranspiration Estimating Methods for the Mantiqueira Range Region, MG, Brazil. Ciência Rural, 39, 2488-2493. http://dx.doi.org/10.1590/S0103-84782009000900016

[41] Souza, A.P., Carvalho, D.F., Silva, L.B.D., Almeida, F.T. and Rocha, H.S. (2011) Reference Evapotranspiration Estimates in Different Cloudiness Conditions. Pesquisa Agropecuária Brasileira, 46, 219-228.

[42] Pilau, F.G., Battisti, R., Somavilla, L. and Righi, E.Z. (2012) Performance of Methods for Estimating Reference Evapotranspiration in the Municipalities of Frederico Westphalen and Palmeira das Missões, State of Rio Grande do Sul, Brazil. Ciência Rural, 42, 283-290.

[43] Oliveira, R.Z., Oliveira, L.F.C., Wehr, T.R., Borges, L.B. and Bonono, R. (2005) Comparative Study of Estimative Models for Reference Evapotranspiration for the Region of Goiânia, GO. Journal of Biosciences, 21, 19-27.

[44] Oliveira, L.F.C., Carvalho, D.F., Romão, P.A. and Cortês, F.C. (2001) Comparative Study of Estimative Models for Reference Evapotranspiration for Selected Sites in Goiás and Distrito Federal. Pesquisa Agropecuária Tropical, 31, 121-126.

[45] Oliveira, G.M. and Leitão, M.M.V.B.R. (2000) Evapotranspiration Estimates and Consequences Due to Errors in the Determination of the Net Radiation and Advective Effects. Revista Brasileira de Engenharia Agrícola e Ambiental, 4, 343-347. http://dx.doi.org/10.1590/S1415-43662000000300007

[46] Fietz, C.R. and Fisch, G.F. (2009) Evaluation of Models to Estimate Net Radiation and the Priestley-Taylor Method in the Region of Dourados, MS, Brazil. Revista Brasileira de Engenharia Agrícola e Ambiental, 13, 449-453.

[47] Nielsen, L.B., Prahm, L.P., Berkowicz, R. and Conradsen, K. (1981) Net Incoming Radiation Estimated from Hourly Global Radiation and/or Cloud Observations. Journal of Climatology, 1, 255-272. http://dx.doi.org/10.1002/joc.3370010305 
Scientific Research Publishing (SCIRP) is one of the largest Open Access journal publishers. It is currently publishing more than 200 open access, online, peer-reviewed journals covering a wide range of academic disciplines. SCIRP serves the worldwide academic communities and contributes to the progress and application of science with its publication.

Other selected journals from SCIRP are listed as below. Submit your manuscript to us via either submit@scirp.org or Online Submission Portal.
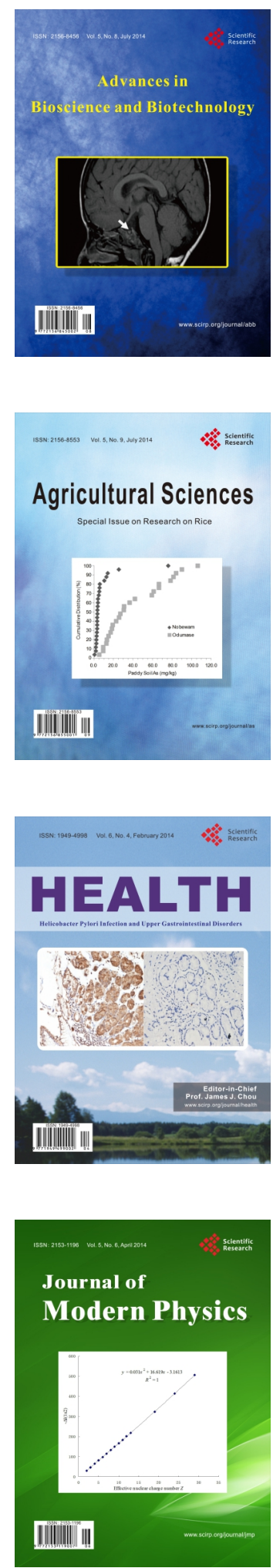
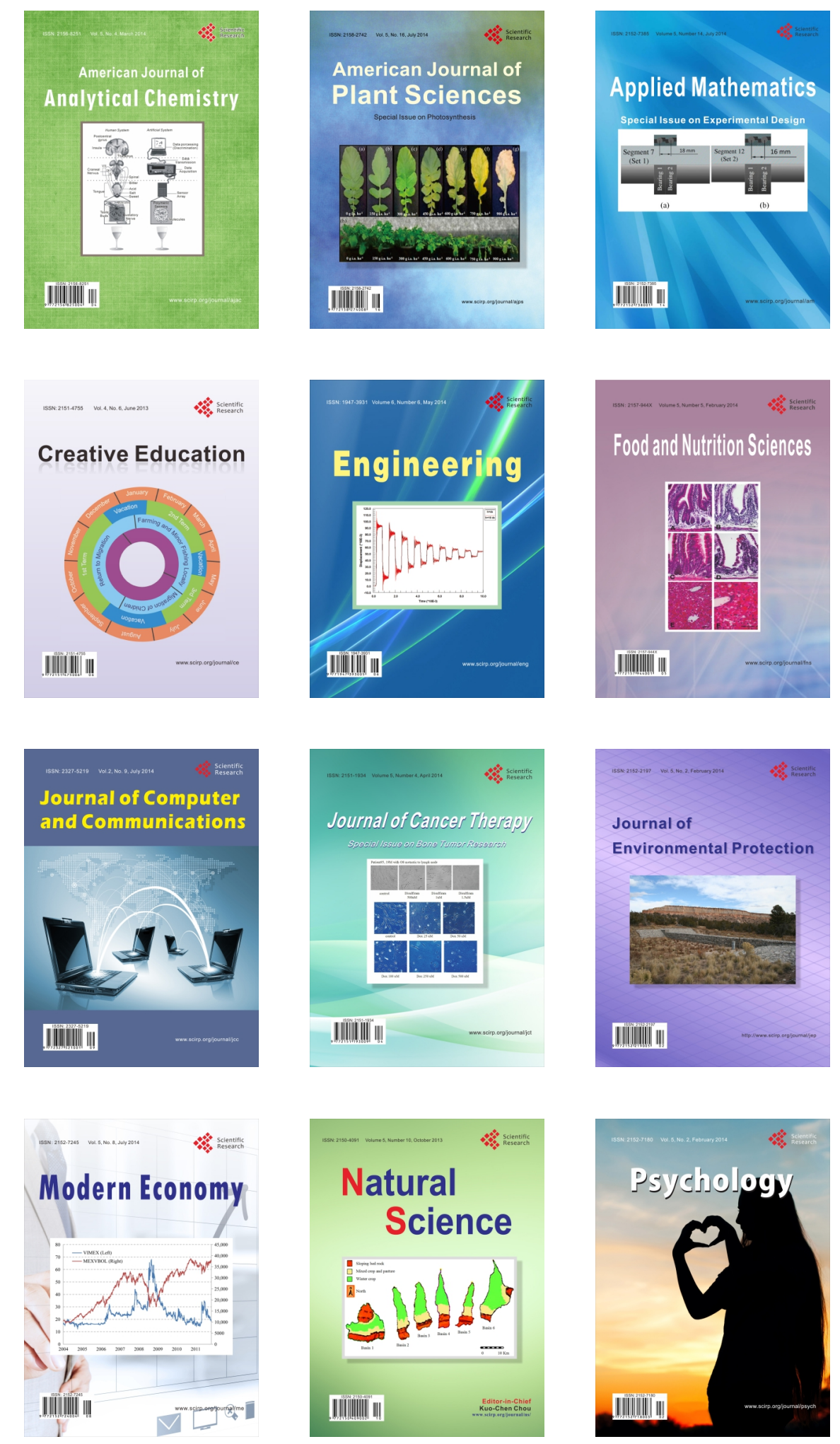